\title{
OPTIMALISASI POTENSI MASJID SEBAGAI BASIS PENGUATAN EKONOMI MIKRO SYARIAH DI BMT MESJID ALMUHSININ CIAMIS
}

\author{
Ganjar Santika ${ }^{1}$, Iip Miftah Fauzi ${ }^{2}$,Wida Lisnawati ${ }^{3}$ \\ ${ }^{1}$ Dosen Perbankan Syariah STEI Ar-risalah Ciamis, ganjarsantika1234@gmail.com \\ ${ }^{2,3}$ Mahasiswa STEI Ar-Risalah
}

\begin{abstract}
The mosque is a religious infrastructure which mostly carries out activities related to devotion to Allah, because the function of the mosque has four main functions, namely as a place of worship, social, educational and economic. Therefore the mosque is not only a place to carry out worship to The Creator, but at the same time facilities muamalah activities. This study aims to determine, describe and analyze the optimization of the role of the al-Muhsinin mosque as a place of worship that is integrated with the service of the people as strengthening the economy of rural communities. This research was conducted with a qualitative approach with the method of observation and interviews with informants who were considered to understand the system applied to the Cisontrol village mosque-based economy. Data analysis used is interactive data analysis. The main purpose of the establishment of a mosque-based economy in the village of Kubang Cisontrol village is to meet the needs of the community for food needs before the month of Ramadan and various other goods so that it does not fall into the ribawi gorge.
\end{abstract}

Keywords: Optimizing the Role of the Mosque, Strengthening the Economy, Ribawi.

\begin{abstract}
ABSTRAK
Masjid merupakan prasarana peribadatan yang sebagian besar melakukan kegiatan yang berkaitan dengan ketaqwaan kepada Allah swt, karena fungsi masjid memiliki 4 fungsi utama yaitu sebagai tempat ibadah, sosial kemasyarakatan, pendidikan dan ekonomi. Oleh karena itu masjid bukan hanya sebagai tempat melaksanakan peribadahan kepada sang khaliq, melainkan sekaligus fasilitas kegiatan muamalah. Penelitian ini bertujuan untuk mengetahui, mendeskripsikan dan menganalisis optimalisasi peran masjid al-Muhsinin sebagai tempat peribadahan yang terintegrasi dengan pelayanan umat sebagai penguatan perekonomian masyarakat pedesaan. Penelitian ini dilakukan dengan pendekatan kualitatif dengan metode observasi dan wawancara kepada informan yang dianggap memahami sistem yang diterapkan terhadap ekonomi berbasis masjid desa Cisontrol. Analisis data yang digunakan adalah analisis data interaktif. Tujuan utama pembentukan ekonomi berbasis mesjid di dusun kubang desa Cisontrol ini adalah untuk memenuhi kebutuhan masyarakat akan sembako menjelang bulan ramadhan dan berbagai kebutuhan barang lainnya sehingga tidak terjerumus pada jurang ribawi.
\end{abstract}

Kata Kunci: Optimalisasi Peran Masjid, Penguatan Perekonomian, Ribawi. 


\section{PENDAHULUAN}

Mesjid merupakan prasarana peribadahan yang tak luput dari kegiatan spiritual dan kultural umat muslim. Keberadaan mesjid menjadi ciri eksistensi umat muslim dan menjadi sentral bagi kegiatan kehidupan sosial kemasyarakatan. Keberadaan fungsi mesjid pada saat ini perlu dioptimalisasikan mengingat mesjid saat ini bukan hanya sebagai pusat peribadahan, melainkan sebagai pusat penguatan ekonomi masyarakat sehingga dapat memberikan manfaat lebih besar.

Apabila merujuk pada masa rasulullah dan para sahabatnya, masjid menjadi pusat aktivitas umat islam. Lebih dari itu problematika umat yang menyangkut bidang agama, ekonomi, sosial dan budaya dipecahkan dilembaga masjid tersebut. Sehingga pada saat ini sangat cocok untuk mengoptimalisasikan masjid sebagai pusat dalam mengembangkan kekuatan ekonomi masyarakat muslim, karena ekonomi yang dibangun dari bawah cenderung akan lebih kuat dibandingkan langsung ditujukan dari atas ke bawah, hal demikian otomatis secara perlahan akan menguatkan perekonomian indonesia pada umumnya.

Kemiskinan dan kelangkaan bahan pangan merupakan fenomena yang tidak biasa lagi untuk saat ini, khususnya di Indonesia. Kelangkaan bahan pangan menyebabkan harga-harga barang yang bersangkutan menjadi naik secara terus menerus dan menyebabkan daya beli masyarakat berkurang. Hal demikian dapat diakibatkan karena sistem regulasi pemerintahan yang tidak dapat berjalan seimbang sehingga diperlukannya sistem baru yang mendorong semangat perekonomian masyarakat dari lapisan bawah agar mampu memenuhi kebutuhan dan daya beli masyarakat menguat.

Masjid al-Muhsinin merupakan masjid jamie dusun Kubang desa Cisontrol yang mengelola sistem keuangan RW 12 desa Cisontrol berbasis tabungan SEMAR (Sembako Ramadhan) sejak tanggal 9 september 2009 yang bernama BMT al-Muhsinin, mengingat kebutuhan akan sembako menjelang hari raya selalu meningkat harganya. Semakin berjalan hingga pada saat ini banyak permintaan masyarakat bukan saja sembako melainkan barangbarang kebutuhan masyarakat lainnya dan BMT al-Muhsinin memberikan pembiayaan tersebut dengan sistem akad murabahah.

Gagasan utama tersebut muncul karena tidak adanya lagi penyumbang utama masjid alMuhsinin untuk aktivitas keagamaan, sehingga masyarakat sekitar masjid al-Muhsinin berpikir secara kreatif dan mandiri untuk memenuhi kebutuhan kegiatan peribadahan dan pada tanggal 9 September 2009 terbentuklah BMT al-Muhsinin dengan konsep SEMAR (Sembako Ramadhan). Konsep tersebut muncul dengan tujuan untuk membantu memenuhi kebutuhan masyarakat menjelang bulan ramadhan mengingat harga barang-barang pokok menjadi mahal pada bulan ramadhan. Dari aktivitas dan tujuan tersebut sampai sekarang barang yang dibiayai secara konsumtif semakin bertambah, seperti permintaan pembiayaan barang elektronik dan kebutuhan kecil lainnya. Teknisnya masyarakat harus mendaftarkan diri terlebih dahulu sebagai nasabah penabung kemudian dapat melakukan pembiayaan, adapun pada saat menjelang ramadhan apabila tidak dibelikan pada barang yang dibutuhkan maka akan dikembalikan sebesar jumlah yang terkumpul selama 10 bulan. 
Menurut Alwi (2015:150) pemberdayaan ekonomi berbasis masjid memiliki potensi yang bagus karena didukung oleh sumber daya manusia yang terus mengalami peningkatan baik itu dari sisi keilmuan maupun pengalaman, sehingga penetapan sumber daya manusia dalam bidang manajemen harus secara selektif yang ahli, jujur dan ikhlas. Hal serupa ditemukan pada ekonomi Berbasis masjid BMT al-Muhsinin yang mana gagasan ekonomi berbasis masjid muncul dan dikelola karena adanya peningkatan kualitas sumber daya manusia. Masyarakat mampu melihat peluang dan kemanfaatan yang begitu besar sehingga pemberdayaan ekonomi kemasyarakatan dapat berjalan demi memenuhi kebutuhan kelompok masyarakat tersebut.

\section{LITERATUR REVIEW}

\section{Fungsi Masjid}

Menurut Muslim (2004:107) masjid berasal dari isim makan dari kata "sajada""yasjudu”-"sujudan" yang artinya tempat sujud, dalam rangka beribadah kepada Allah atau dengan kata lain sebuah tempat yang dapat digunakan untuk melaksanakan ibadah shalat. Meski demikian mendirikan shalat boleh dilakukan tidak hanya dimasjid, seperti sebuah keterangan sabda nabi SAW “... dijadikan bagiku seluruh bumi sebagai tempat sujud (masjid) dan tanahnya dapat digunakan untuk bersuci ...." (HR. Muslim). Dari keterangan tersebut dapat diketahui bahwa melaksanakan ibadah shalat tidak mutlak pada suatu tempat saja, tetapi dapat dilaksanakan diberbagai tempat dengan syarat memenuhi ketentuan-ketentuan yang teah ditetapkan.

Menurut Muslim (2004:107) masjid secara sosiologis diartikan sebagai tempat atau bangunan tertentu yang diperuntukan bagi orang-orang muslim untuk mengerjakan shalat yang terdiri dari shalat wajib dan shalat sunah, baik dilakukan secara perseorangan maupun secara berjamaah. Selanjutnya masjid sebagai tempat dilakukannya kegiatan ibadah shalat jum'at dinamakan sebagai masjid jami' selain dari pada itu masjid yang dapat dilakukannya ibadah shalat wajib dan rawatib saja dinamakan mushalla. Dalam Muslim kata ini merujuk pada kata "shalla" - "Yushalli" - "shallatan" yang memiliki makna sebagai tempat melakukan ibadah shalat.

Pada awal perkembangan dan perjalanan dakwah Rasulullah SAW dalam menyebarkan agama islam yang pertama beliau bangun adalah masjid sebagai pusat pengembangan ajaran islam. Dari agungnya masjid beliau memulai membina masyarakat dengan berbagai ras, suku, dan agama, hingga terbentuklah masyarakat yang beliau bina sebagai orang-orang muslim yang berhasil dengan baik dan menjadi pemimpin pada masanya.

Menurut muslim (2004:108) fungsi masjid pada masa Rasulullah SAW Adalah:

a. Sebagai tempat melaksanakan ibadah mahdhah.

b. Sebagai pusat pendidikan dan pengajaran islam.

c. Sebagai pusat informasi islam.

d. Sebagai tempat menyelesaikan perkara hukum dan keadilan.

e. Sebagai tempat kegiatan sosial, politik dan ekonomi. 
Menurut Saputra dan Bayu (2017:8) peranan masjid pada umumnya saat ini adalah ibadah atau pembinaan iman dan taqwa, sosial kemasyarakatan, pendidikan dan pembinaan sumber daya insani, serta pembinaan ekonomi umat. Dalam perkembangannya peranan masjid dalam pembangunan ekonomi umat bermanfaat dalam membantu masyarakat agar terhindar dari jeratan bunga yang dimaknai "ziyadah" dalam ekonomi islam. Ziyadah merupakan arti bahasa dari riba yang artinya tambahan atau kelebihan. Para jumhur ulama berpendapat bahwa riba sendiri ialah penambahan atas harta pokok yang seiring berjalannya waktu akan semakin bertambah. Hal tersebut bermakna bahwa dalam transaksi jual beli ataupun pinjam meminjam jika peminjam tidak bisa membayar dalam aktu jatuh tempo, maka nilai atau harga yang harus dibayarkan kepada pemberi pinjaman atau penjual akan menjadi bertambah.

Penelitian yang dilakukan oleh Alwi (2012:150) menyatakan bahwa kondisi ril masjid saat ini masih jauh dari contoh masjid pada zaman rasulullah SAW, kondisi tersebut diperparah oleh persepsi sebagian masayarakat yang belum bisa menerima multifungsi masjid dalam banyak aspek kehidupan termasuk pemberdayaan ekonomi masyarakat dan jamaahnya, meskipun demikian, pemberdayaan ekonomi masyarakat memiliki prospek yang cukup cerah dimana didukung oleh kondisi masayrakat yang terus mengalami transfrmasi kearah modernisasi, tinggal bagaimana menyiapkan tenaga di bidang manajemen yang ahli dan memiliki ahlakul karimah.

Berdasarkan penelitian yang dilakukan oleh Suryanto (2012:24) potensi yang dimiliki masjid jami di lingkungan kota Tasikmalaya meliputi potensi dana masjid yang terhimpun tiap bulan yang bersumber dari sumbangan individu, bantuan pemerintah sumbangan organisasi perusahaan disamping itu terdapat masjid yang sudah memiliki baitul maal meskipun masih dalam bentuk yang sangat sederhana, potensi kegiatan masjid yang dapat mendukung untuk pemberdayaan adalah pengalaman DKM masjid dalam penglolaa zakat fitrah dan kegiatan rutin majlis taklim.

\section{Pemberdayaan Ekonomi Islam di Masyarakat}

Rapaport dalam Suryanto (2012:9) mengungkapkan bahwa pemberdayaan suatu cara dimana rakyat mampu menguasai kehidupannya, sedangkan Craig dan Mayomengatakan bahwa konsep pemberdayaan merupakan pengembangan masyarakat yang terkait dengan konsep kemandirian, partisipasi, jaringan kerja dan pemerataan.

Menurut Hutomo dalam Suryanto (2012:10) pemberdayaan ekonomi adalah penguatan kepemilikan faktor-faktor produksi, distriusi dan pemasaran, penguatan utnuk mendapat upah atau gaji yang memadai, penguatan untuk memperoleh informasi, pengetahuan dn keterampilan, yang harus dilakukan dengan multi aspek baik dari aspek massyarakatnya maupun dari aspek kebijaksanaannya.

Menurut Ginanjar Kartasasmita dalam Suryanto (2012:0) pemberdayaan ekonomi merupakan upaya pengarahan sumber daya dalam mengembangkan potensi ekonomi masyarakat untuk meningkatkan produktivitas. Beberapa konsep ekonomi isalam dinyatakan 
dalam al-Qur'an yaitu kehidupan yang baik (hayatan thayyiban) dan kesejahteraan (fala), pemberian kemudahan dan pengentasan penderitaan, generasi kemakmuran. Berdasarkan hal tersebut pemberdayaan dalam ekonomi islam tidak untuk menghancurkan yang kuat ataupun menyamaratakan kekuasaan, tetapi sebagai jalan tengah.

Menurut Suryanto (2102:11) komponen-komponen pemberdayaan ekonomi adalah:

a. Lembaga atau organisasi pemberdayaan yang berfugsi sebagai wadah yang dibentuk oleh masyarakat sebagai organisasi dalam melakukan perencanaan, pelaksanaan dan pengendalian pemberdayaan masyarakat.

b. Partisipasi individu dalam bentuk kelompok pemberdayaan.hal ini sangat diperlukan untuk mewujudkan partisipasi masyarakat yang aktif dan kreatif dan inovatif, karena pemberdayaan mengacu pada kemampuan masyarakat untuk mendapatkan dan emmanfaatkan akses dan pengendalian terhadap sumber daya tertentu.

c. Pembiayaan Modal yang merupakan penyaluran dana. Menggunakan istilah pembiayaan karena penyaluran dana yang dilakukan secara bertahap dan bersifat produktif.

d. Pendampingan yang merupakan fasilitator dalam proses pemberdayaan. Oleh karena itu proses tersebut sangat penting karena anggota pemberdayaan terkadang memiliki rantai ketidakberdayaan sehingga memerlukan pihak lain yang berfungsi sebagai pemberi solusi.

e. Pendidikan dan pelatihan. Dalam proses pemberdayaan proses belajar dibutuhkan untuk memupuk pengetahuan kelompok pemberdayaan masyarakat.

Berdasarkan penelitian yang dilakukan oleh Ruslan (2012:24) menyatakan bahwa konsep pemberdayaan ekonomi masyarakat yang berbasis masjid berfungsi sebagai tawaran dari suatu metode dalam mengikis habis kemiskinan.

Penelitian yang dilakukan oleh Alwi (2015:150) pemberdayaan ekonomi yang dilakukan akan berjalan baik jika ada kerjasama yang optimal dari semua pihak yang terlibat. Faktor yang dapat mendukung pemberdayaan secara maksimal diantaranya ketersediaan dana, keterlibatan secara aktif, adanya penggerak yang progresif, dan semua unsur yang dibutuhkan dalam tindakan kerjasama.

\section{METODE}

Penelitian ini dilakukan pada BMT Al-Muhsinin (Masjid al-Muhsinin) dusun Kubang RW 12 desa Cisontrol, Kecamatan Rancah, kabupaten Ciamis, Jawa Barat, Indonesia. Bahan dan data yang digunakan dalam penelitian ini berasal dari hasil observasi dan wawancara dengan informan yang dianggap memahami sistem ekonomi berbasis masjid yang digunakan di BMT al-Muhsinin. Metode penelitian menggunakan pendekatan kualitatif dengan meneliti keadaan perekonomian masyarakat dan kondisi lingkungan masyarakat RW 12 Dusun Kubang 
desa Cisontrol yang kemudian ditafsirkan dengan penafsiran data yang diperoleh dari hasil observasi dan wawancara.

\section{HASIL DAN PEMBAHASAN}

\section{Optimalisasi Fungsi Masjid sebagai pemberdayaan Ekonomi}

Menurut Ruslan (2012:19) konsep pemberdayaan dalam beberapa dekade terahir ini ramai didiskusikan oleh para akademisi, dan kemudian mulai muncul kepermukaan pada tahun 1970-an sampai pada akhir abad 20-an. Secara singkat pemberdayaan diartikan sebagai cara dimana manusia (rakyat) mampu menguasai kehidupannya sehingga dapat mengendalikan masalah dengan berbagai cara yang mereka dapatkan baik melalui keilmuan ataupun pengalaman.

Menurut Suryanto (2019:9) konsep pemberdayaan merupakan pengembangan masyarakat yang lebih terkait pada kemandirian, partisipasi, jaringan kerja dan pemerataan. Konsep tersebut bertujuan untuk menggali dan menemukan cara-cara baru dalam pembangunan ekonomi masyarakat. Konsep pemberdayaan ekonomi masyarakat dianggap juga sebagai konsep pembangunan yang lebih berpusat pada rakyat yang meletakan partisipasi aktif masyarakat secara efektif, efisien dan sikap kemandirian rakyat. Pemberdayaan yang mulai dibangun di Indonesia saat ini adalah konsep pembangunan yang lebih mengarah pada model perencanaan dan kebijakan yang bersifat top down, sedangkan pemberdayaan masyarakat lebih bersifat bottom up..

Menurut Suryanto (2016:10) Pemberdayaan ekonomi masyarakat merupakan sebuah metode pengerahan seluruh potensi sumber daya untuk mengembangkan dan meningkatkan produktivitas masyarakat baik dari sumber daya alam maupun sumber daya manusia sehingga terdapat peningkatan daya beli masyarakat. Pemberdayaan ekonomi masyarakat dalam upaya peningkatan kualitas produktivitas usaha masyarakat diataranya harus mencakup peningkatan askes masyarakat terhadap modal usaha, peningkatan akses masyarakat terhadap peningkatan kualitas sumber daya manusia dan peningkatan akses masyarakat terhadap sarana dan prasarana yang mendukung sosial ekonomi masyarakat. Dalam persfektif islam konsep pemberdayaan telah disebutkan sejak 1400 abad yang lalu yang ditandai dengan banyaknya ayat al-Qur'an dan hadits yang apabila digabungkan merujuk pada spirit pemberdyaan dengan landasan rahmatan lil'aalamin, beberapa manifestasi rahmatan lil'aalamin dinyatakan secara eksplisit dalam alQur'an, antara lain pembinaan kehidupan yang baik (hayatan thayyiban) dan kesejahteraan (falah).

Menurut Saputra dan Bayu (2017:6) fungsi masjid yang paling utama adalah sebagai pusat peribadahan umat muslim, secara terminologis fungsi masjid adalah melakukan kegiatan yang berkaitan dengan ketaqwaan kepada Allah swt, karena fungsi masjid memiliki 4 fungsi utama yaitu sebagai tempat ibadah, sosial kemasyarakatan, pendidikan dan ekonomi. Oleh karen itu masjid dapat diartikan secara luas, bukan hanya sebagai tempat melaksanakan ritual peribadahan kepada sang khaliq. 
Menurut Alwi (2015:136) masjid memiliki dua misi utama dalam kedudukannya sebagai prasarana peribahan. Yang pertama sebagai prasarana pembersihan diri yang sifatnya vertikal (habluminallah). Misi kedua adalah sebagai pembebasan dan pemberdayaan dimana masjid berperan mewujudkan masyarakat yang sejahtera, tidak diperbudak oleh keinginan yang tidak terbatas, sehingga masyarakat dapat mencari pendanaan yang tidak berkah. Masjid seperti demikian tidak hanya dijumpai di zaman modern saja, melainkan telah dicontohkan pada zaman rasul dan sahabat.

Seperti halnya masjid yang terdapat di desa Cisontrol, yang mana dikelola tidak hanya bagi kepentingan ibadah saja, melainkan juga bagi kegunaan pemberdayaan masyarakat terutama bidang ekonomi. Masjid al-Muhsinin yang terdapat di dusun Kubang desa Cisontrol menyediakan layanan sosial kemasyarakatan melalui pembangunan ekonomi yang bersifat bottom up, berupa tabungan masyarakat yang dapat dimaksimumkan keproduktifan dananya selama 10 bulan dalam setiap tahun buku. Hal tersebut membantu masyarakat ekonomi lemah untuk mendapatkan kebutuhan mereka melalui pembiayaan konsumtif berupa barang modal dengan menggunakan sistem syariah.

Menurut Oktavia (2014:129) secara filosofis orientasi ekonomi islam dilandaskan pada asas ketuhanan (tauhid) yang mana memiliki makna bahwa adanya hubungan dari aktivitas ekonomi tidak hanya dengan sesama manusia, melainkan juga hubungannya dengan Allah SWT sebagai sang pencipta. Berdasarkan yang dikemukakan oleh Basd (2009:120) berlandasarkan landasan tauhid ini kemudian muncul prinsip-prinsip yang menjadi nilai bagi kehidupan manusia diantaranya seperti prinsip kekhilafahan, keadilan, dan persaudaraan, disamping itu terdapat nilai-nilai instrumental seperti anjuran menunaikan zakat, jaminan sosial, kerjasama dalam perekonomian, dan pelarangan riba.

\section{BMT berbasis Masjid dalam Perekonomian Masyarakat}

BMT (Baitul Maal wa Tamwil) berbasis masjid merupakan sebuah wadah yang mana dapat memberikan sebuah dukungan mendasar terhadap kualitas ekonomi mikro dan kecil kebawah berlandaskan pada ketentuan syariah. lembaga ini berdiri dengan 2 fungsi yaitu Baitul Maal yaitu menghimpun dana dan menyalurkan dana seperti dana zakat, infaq dan shadaqah. Sedangkan Baitul Tamwil yaitu kegiatan dalam dalam memproduktifkan dan menginvestasikan dana dalam rangka meningkatkan ekonomi mikro kecil kebawah diantaranya dengan memotivasi kegiatan menabung dan pembiayaan bagi masyarakat. Berdasarkan uraian diatas maka BMT merupakan lembaga keuangan yang beroperasi berlandaskan hukum syariah karena fungsi dan peranan BMT sebagai penghimpun dan penyalur dana baik dana bisnis maupun dana infaq. BMT bukan saja semata-mata sebagai lembaga sosial, melaikan lembaga keuangan yang dihalalkan dalam mencari profit melalui metode yang tidak diharamkan oleh syariat islam.

Menurut Basd (2009:112) Indonesia merupakan negara yang mayoritas penduduknya beragama islam, dan pada saat ini timbul kerinduan pada umat muslim terhadap munculnya lembaga keuangan syariah seperti halnya pada awal peradaban islam, hal tersebut didorong oleh semangat keberagaman yang terus meningkat dan gagalnya lembaga keuangan yang ada 
dalam meningkatkan produktivitas serta bias terhadap tujuan peningkatan kesejahteraan umat, sehingga pada akhir Oktober 1995 di Indonesia berdiri sekitar 300 BMT yang dalam istilah bahasa indonesi disebut dengan Balai Usaha Mandiri. BMT dalam operasionalnya memadukan beberapa aspek yaitu aspek keagamaan, aspek sosial dan aspek ekonomi. Aspek-aspek tersebut bermaksud untuk melayani masyarakat yang sifatnya penerapan prinsip-prinsip syariah, pertolongan, pemberdayaan dan pengembangan serta peningkatan ekonomi sosial kemasyarakatan yang sifatnya komersial. BMT pada masa kini bertransformasi menjadi lembaga yang membentuk solidaritas sekaligus lembaga ekonomi masyarakat kecil yang menjadi jawaban terhadap problematika dikalangan masyarakat bawah seperti kesenjangan ekonomi dan kemiskinan. Isu pemberdayaan dan kesejahteraan umat adalah hal yang menjadi tujuan dimunculkannya BMT berbasis masjid.

Pembentukan BMT al-Muhsinin Dusun Kubang desa Cisontrol dalam kegiatan ekonomi berbasis Masjid merupakan suatu gerakan dalam rangka menanggulangi berbagai permasalahan ekonomi masyarakat bawah. Fokus pembentukannya adalah menyasar masyarakat yang membutuhkan pembiayaan rendah untuk memenuhi kebutuhan masyarakat itu sendiri dan memenuhi kebutuhan lingkungan sehingga tercipta kesejahteraan di lingkungan masyarakatnya. Ekonomi berbasis masjid yang selanjutnya disebut dengan BMT al-Muhsinin ini menjadi wadah untuk pengumpulan dana yang bersumber dari masyarakat RW 12 dusun Kubang, yang dihimpun setiap minggu pada pengajian hari jum'at yang kemudian dikelola berdasarkan prinsip syariah.

Modal sosial merupakan modal utama dalam menghadapi persoalan yang dihadapi oleh anggota masyarakat dan bergerak karena adanya kepercayaan dari masyarakat terhadap pengelola ekonomi berbasis masjid. Dalam konsep syariah modal sosial sangat dibutuhkan terutama ketertarikan masyarakat dalam menitipkan sebagian dananya yang kemudian dapat diproduktifkan dan dioptimalisasikan dalam rangka menghidupkan fungsi masjid bagi masyarakat itu sendiri.

\section{Manajemen Keuangan BMT Berbasis Masjid}

Menurut (Oktavia 2014: 130) pemberdayaan ekonomi masyarakat kelas bawah tidak dapat dilakukan dengan cara konvensional, karena kegiatan usaha yang dilakukan masih relatif kecil, masih jauh dari masalah legalitas, kelembagaan, manajemen dan pembukuan serta jumlah aset yang dijaminkan untuk mendapatkan pembiayaan modal. Dengan demikian diperlukannya menggunakan pendekatan permodalan dengan menggunakan sistem perbankan meskipun sistem perbankan syariah akan tetap sulit bagi masyarakat. Berdasarkan hal tersebut cara yang efektif menurut beberapa pakar akademisi adalah dengan membentuk lembaga keuangan berbasis masjid yang dapat juga realisasinya berupa Baitulmaal Wattamwil.

Adapun fungsi dari pada BMT itu sendiri seperti yang telah disebutkan diatas sebagai Baitulmaal dan Baitul Tamwil. Dasar daripada pembentukan BMT al-Muhsinin sebagai lembaga ekonomi berbasis masjid berlandaskan pada QS. Al-baqarah:275 yang berbunyi “ .... Allah telah menghalalkan jual beli dan mengharakan riba...." Dalam BMT berbasis masjid di 
kawasan dusun Kubang RW 12 desa Cisontrol kecamatan Rancah tekhnik funding atau penghimpunan dana dilakukan dengan sistem tabungan dari masyarakat RW 12 setiap minggu ketika pengajian ibu-ibu pada hari jum'at dilaksanakan dengan jumlah nominal tabungan yang dibebaskan setiap kali menabung. Jangka waktu tabungan masyarakat berkisar 10 sampai dengan 11 bulan, syawal hingga sya'ban dan pada saat bulan ramadhan tabungan tersebut dibagikan sesuai dengan jumlah yang terhimpun. Dapat dikatakan bahwa masyarakat tidak menerima bagi hasil dari aktivitas pemroduktifkan dana masyarakat, sehingga dapat dikatakan bahwa tabungan masyarakat tersebut menggunakan sistem akad wadiah. Hal tersebut mendorong dan mendidik secara tidak langsung kepada masyarakat agar memiliki semangat menabung yang tinggi. Aktivitas tersebut sama sekali tidak mengganggu dan tidak menghilangkan niat suci dalam kegiatan peribadahan, karena secara teknis penyerahan uang dari masyarakat (nasabah) dan pencatatan oleh petugas dilakukan sebelum atau sesuadah pengajian selesai.

Adapun lending atau penyaluran pembiayaan ke masyarakat dari BMT al-Muhsinin ini dilakukan dengan menggunakan sistem akad murabahah. Menurut Harahap dkk (2010:111) sistem akad murabahah memiliki pengertian yaitu akad jual beli barang dengan menyatakan harga perolehan dan keuntungan (margin) yang disepakati oleh oleh penjual dan pembeli. Sedangkan dalam fatwa DSN-MUI (fatwa 2006) yang dimaksud dengan murabahah adalah menjual suatu barang dengan menegaskan harga belinya kepada pembeli dan pembeli membayarnya dengan harga yang lebih sebagai margin atau laba. Dapat disimpulkan bahwa BMT al-Muhsinin berbasis masjid di dusun kubang RW 12 ini hanya melayani pembiayaan berupa barang. Barang yang dibiayai berupa barang kecil bagi kebutuhaan masyarakat seperti barang elektonik, mebeul dan barang lainnya. Adapun pembiayaan bagi kebutuhan usaha perniagaan, mekanisme pembiayaan tetap menggunakan akad murabahah berupa pembelian barang modal yang dibutuhkan dalam aktivitas jual beli nasabah. Dikarenakan akad sistem akad yang digunakan adalah akad murabahah maka proses pembayarannya dilakukan secara tangguh maksimal selama 10 bulan dalam jangka waktu 1 tahun dengan tingkat margin $20 \%$ per 10 bulan. Hal demikian terjadi karena dana yang terhimpun sebagai modal yang diproduktifkan berasal dari tabungan ramadhan masyarakat yang terkumpul dari syawal hingga sya'ban dan harus dikembalikan lagi kepada masyarakat selaku nasabah sesuai dengan jumlah yang terhimpun.

Kriteria pemberian pembiayaan sangat diperhatikan di BMT basis masjid tersebut, karena pengurus harus menjaga (trust) kepercayaan pihak nasabah penyimpan. Pemberian pembiayaan yang diberikan memperhatikan aspek moralitas yaitu karakter yang terdapat dalam pribadi nasabah pembiayaan minimal memiliki 4 sifat yang dimiliki oleh rasulullah SAW dan aspek kapasitas yaitu sejauh mana kemampuan nasabah pembiayaan dapat membayar sejumlah angsuran yang diambil berdasarkan latar belakang pendapatan calon nasabah pembiayaan. Dalam praktinya pembayaran angsuran pembiayaan setiap bulannya tidak flat, melainkan sesuai dengan kemampuan nasabah asalkan dapat terselesaikan dalam jangka waktu 10 bulan. Adapun nasabah yang terkena kendala dalam pembayarannya, BMT al-Muhsinin sebagai salah 
satu lembaga ekonomi berbasis masjid dapat meresceduling waktu pembayarannya dengan tidak menarik tambahan pembayaran, sehingga dapat meringankan beban masyarakat.

Selain BMT al-Muhsinin dusun Kubang desa Cisontrol kecamatan Rancah sebagai ekonomi basis masjd tidak hanya berorientasi profit tetapi berorientasi bagi pemberdayaan sosial masyarakat. Hasil dari pada pengelolaan dana masyarakat selama kurang lebih 10 sampai 11 bulan tidak semata-mata digunakan bagi kepentingan individu atau kelompok tertentu, melainkan digunakan untuk memenuhi kebutuhan dan kepentingan di lingkungan masyarakat seperti dana pendukung program dusun, dana pendukung program masjid, pembiayaan transport kesehatan bagi warga yang membutuhkan, pembelian kain kafan ketika ada yang wafat serta digunakan sebagian kecil bagi kesejahteraan pengurus.

Dalam 10 tahun operasionalnya BMT al-Muhsinin dusun kubang RW 12 desa Ciosntrol sebagai ekonomi basis masjid ini belum sampai meluas ke RW lainnya kerana setelah dicoba beberapa waktu kebelakang masyarakatnya tidak selancar masyarakat RW 12 pada saat melaksanakan akad transaksi. Namun disamping itu BMT al-Muhsinin ini juga telah memiliki pemekaran di dusun Harjamukti desa Cisontrol dengan nama BUMDUS Raharja yang baru beroperasi sekitar 4 minggu, konsep yang diterapkan sama dengan di dusun Kubang RW 12, namun kelebihannya BUMDUS Raharja telah memiliki pemberdayaan ekonomi umat melalui unit usaha gas dan air mineral sehingga keuntungan yang disalurkan pada masyarakat dusun menjadi lebih besar. Sementara itu di BMT dusun Kubang masih terbatas pada pembiayaan konsumtif saja, belum sampai pada pembiayaan produktif dikarenakan oleh minimnya permodalan dan mindset masyarakat sebagai nasabah pembiayaan yang kurang memperhatikan pengembalian pembiayaan yang dana atau modalnya berasal dari luar masyarakat atau nasabah penabung. Sampai sejauh ini praktik BMT al-Muhsinin sebagai lembaga ekonomi berbasis masjid telah memberikan dampak positif bagi masyarakat sekitarnya sehingga dengan maraknya lintah darat dikalangan masyarakat yang membutuhkan dana cepat dan mudah dapat teratasi dengan sistem yang baik dan halal.

\section{KESIMPULAN}

Fungsi utama masjid merupakan sebagai sarana peribadahan umat muslim yang pada saat ini fungsi masjid tidak hanya berfokus dalam ibadah secara vertikal melainkan dapat dioptimalisasikan fungsinya sebagai prasarana pendidikan dan perekonomian umat. Dalam kaitannya sebagai realisasi dari fungsi perekonomian, masjid al-Muhsinin dusun kubang RW 12 desa Cisontrol membentuk perekonomian berbasis masjid yang dapat dinamakan sebagai BMT al-Muhsinin. Gagasan tersebut muncul karena terdesaknya kebutuhan umat dan berhentinya donatur utama masjid tersebut, sehingga masjid menginginkan kesejahteraan masyarakat yang berasal dari aktivitas usaha masjid itu sendiri. BMT al-Muhsinin dusun kubang RW 12 berdiri berlandaskan ketentuan ayat al-Qur'an yang mana Allah telah menghalalkan jual beli dan mengharamkan riba. Oleh karena itu aktivitas funding dan lending nya pun berdasarkan pada ketentuan syariat islam. Dari keuntungan yang diperoleh BMT alMuhsinin tidak semata-mata memupuk kekayaan kelompok tertentu, melainkan disalurkan 
demi kepentingan umat, sehingga dengan adaya ekonomi berbasis masjid tersebut dapat memberikan dampak yang positif bagi masyarakat sekitar RW 12 sehingga mengurangi keleluasaan jurang ribawi.

\section{REFERENSI}

Al-Qur'an Terjemah dan Asbabun Nuzul. Pustaka al-Hanan: Surakarta.

Alwi, Muhammad Muhib. 2015. Optimalisasi Fungsi Masjid dalam Pemberdayaan Ekonomi Masyarakat. Jurnal al-Tatwir. Vol 2 No. 1.

Basd, Abd. 2009. Pemberdayaan Ekonomi Umat Berbasis Masjid (Pengalaman BMT Masjid Nurul Jannah Petrokimia Gresik). Jurnal Al-Qanun. No. 01. Vol. 12.

Harahap, Sofyan S. Wiroso dan M. Yusuf. 2010. Akuntansi Perbankan Syariah. LPFE Usakti: Jakarta. hlm. 111.

Oktavia, Renny. 2014. Peranan Baitul Maal Wattamwil (BMT) Terhadap Upaya Perbaikan Moral Masyarakat di Kawasan Dolly Surabaya. Jurnal An-Nisbah. No. 01. Vol. 01.

Ruslan, Ismail. 2012. Pemberdayaan Ekonomi Masyarakat Berbasis Masjid di Pontianak. Jurnal Khatulistiwa-Journal Of Islamic Studies, vol 2 No. 1.

Saputra, Ary dan Bayu Mitra Adhyatama K. 2017. Revitalisasi Masjid dalam Dialektika Pelayanan Umat dan Kawasan Perekonomian Rakyat. Jurnal manajemen dan Administrasi Islam, Vol 1, No. 1.

Suryanto, Asep. 2016. Optimalisasi fungsi dan Potensi Masjid: Model Pemberdayaan Ekonomi Masyarakat Berbasis Masjid di Kota Tasikmalaya. Jurnal Iqtishoduna. Vol. 8. No. 2. 